\title{
ANALISIS KEBUTUHAN PENGEMBANGAN MEDIA AUDIO VISUAL POKOK BAHASAN SINTESIS PROTEIN UNTUK SMA
}

\author{
Ima Nurani, Muh Amir Masruhim, Evie Palenewen \\ Program Studi Pendidikan Biologi, FKIP, Universitas Mulawarman. \\ Email : nurani28@gmail.com
}

\begin{abstract}
The aim of this study is to obtain 1) description of the use of learning media as teaching resource on biology learning process that has been happening in the field 2) the views and constraints faced by teachers in the field for delivering protein synthesis subject. 3) formulation of learning media that needs to be developed on biology learning of protein synthesis subject. The observation result was in the form of teacher's needs assessment instrument that analyzed using descriptive qualitative obtained that the use of learning media as teaching resource on biology learning process that has been happening in the field has not done optimally. There are constraints in delivery of material, especially material that cannot be observed directly or abstract. 2) The protein synthesis subject is a difficult subject, in its delivery, teachers need media that can visualize the process of protein synthesis for twelfth grade and explain it in detail and correctly so there is no misconception of students towards protein synthesis subject. 3) The learning media that needs to be developed in biology learning of protein synthesis subject is in the form of audiovisual media.
\end{abstract}

Keywords: Needs Assessment, media, audiovisual, protein synthesis.

Abstrak: Tujuan dari penelitian ini adalah untuk memperoleh: 1) deskripsi penggunaan media pembelajaran sebagai sumber pembelajaran dalam proses pembelajaran biologi di lapangan, 2) pandangan dan kendala yang dihadapi guru di lapangan untuk memberikan materi sistesis protein, 3) formulasi media pembelajaran yang perlu dikembangkan dalam pembelajaran biologi tentang sintesis protein.

Hasil pengamatan adalah dalam bentuk instrumen needs assessment guru yang dianalisis menggunakan deskriptif kualitatif. Pengamatan menemukan bahwa penggunaan media pembelajaran sebagai sumber belajar dalam proses pembelajaran biologi telah dilakukan di lapangan, namun belum dilaksanakan secara optimal, yaitu: 1) ada kendala dalam penyampaian materi, terutama materi yang tidak dapat diamati langsung atau abstrak, 2) materi sintesis protein adalah materi yang sulit dalam penyampaiannya, guru perlu media yang dapat memvisualisasikan proses sintesis protein untuk kelas dua belas dan menjelaskannya secara rinci dan benar sehingga tidak ada kesalahpahaman siswa terhadap pelajaran sintesis protein, dan 3) media pembelajaran yang perlu dikembangkan dalam pembelajaran biologi adalah materi sintesis protein dalam bentuk media audio-visual.

Kata Kunci: needs assessment, media , audiovisual, sintesis protein 


\section{Pendahuluan}

Proses pembelajaran merupakan salah satu unsur penting untuk mencapai keberhasilan dalam pembelajaran. Sudjana (2010) mengemukakan bahwa proses belajar mengajar atau proses pengajaran merupakan suatu kegiatan melaksanakan kurikulum suatu lembaga pendidikan agar dapat mempengaruhi para siswa mencapai tujuan pendidikan yang ditetapkan. Sehingga dapat disimpulkan bahwa proses pembelajaran dapat dikatakan efektif jika tujuan pembelajaran yakni pemahaman siswa terhadap konsep pembelajaran dapat tercapai.

Menurut Suhermiati, Indana, \& Rahayu (2015), Pemahaman konsep biologi merupakan salah satu tujuan penting dalam tujuan pembelajaran biologi, yaitu memberikan pengertian bahwa konsepkonsep yang diajarkan kepada siswa tidak hanya sekedar hafalan melainkan harus dipahami. Pemahaman konsep biologi juga merupakan salah satu tujuan pembelajaran yang disampaikan oleh guru, karena guru berperan sebagai pembimbing siswa selama pembelajaran untuk mencapai konsep yang diharapkan.

Pada KTSP 2006 tercantum bahwa siswa kelas XII diharapkan dapat menguasai beberapa kompetensi dasar salah satunya yaitu memahami peran DNA dan RNA dalam sintesis protein (BNSP, 2006). Pokok bahasan sintesis protein tersebut mengandung materi yang bersifat abstrak seperti yang dikemukakan Susantini, Nuur, \& Thamrin (2013). Selain itu, Murni (2013) juga menyatakan bahwa sintesis protein merupakan konsep dengan topik yang sangat luas dan rumit, memuat sejumlah proses yang terjadi di dalam sel sehingga sulit untuk melakukan pengamatan secara langsung, bersifat abstrak, banyak istilah asing, bahasanya sulit dan memiliki tingkat kompleksitas tinggi untuk memahaminya. Berdasarkan cakupan pokok bahasan sintesis protein tersebut, guru dituntut harus dapat memahami dengan benar dan dapat menyampaikannya secara konkret agar siswa dapat mudah memahaminya dan tidak terjadi miskonsepsi atau kesalahan pemahaman konsep.

Salah satu upaya yang dapat digunakan guru untuk menyajikan rangkaian proses sintesis protein secara lebih konkret dan untuk mengatasi adanya miskonsepsi oleh siswa adalah dengan menggunakan media. Sukiman (2012) menjelaskan kegunaan praktis dari media pembelajaran dalam proses belajar mengajar yaitu media pembelajaran dapat memperjelas penyajian pesan dan informasi sehingga dapat memperlancar dan meningkatkan proses dan hasil belajar. Pemanfaatan media pembelajaran seharusnya merupakan bagian yang harus mendapat perhatian bagi guru dalam setiap proses belajar mengajar. Oleh karena itu, guru perlu mempelajari bagaimana memanfaatkan media pembelajaran untuk mengeefektifkan pencapaian tujuan pembelajaran dalam proses belajar mengajar, khususnya untuk beberapa materi yang tergolong sulit dipahami atau bersifat abstrak seperti pokok bahasan sintesis protein.

Berdasarkan latar belakang di atas, penelitian ini perlu dilakukan sebagai kajian awal dalam pengembangan media pembelajaran pokok bahasan sintesis protein untuk kelas XII SMA. Rumusan masalah dalam penelitian ini adalah 1) Bagaimana gambaran penggunaan media pembelajaran sebagai sumber ajar pada proses pembelajaran biologi yang selama ini terjadi di lapangan? 2) Bagaimana pandangan dan kendala yang dihadapi guru-guru di lapangan terhadap penyampaian pokok bahasan sintesis protein?. 3) Bagaimana rumusan media pembelajaran yang perlu dikembangkan dalam pembelajaran biologi pokok bahasan sintesis protein?

\section{Metode}

Penelitian ini merupakan penelitian awal yang termasuk di dalam tahap pra pengembangan dalam prosedur penelitian dan pengembangan(R\&D) oleh Sugiyono (2010). Penelitian ini hanya terbatas pada analisis 
kebutuhan (need assesment) yang bersumber dari hasil observasi awal di lapangan dan juga kajian terhadap literatur-literatur yang relevan dengan penelitian ini. Teknik pengumpulan data dalam penelitian ini menggunakan instrumen analisis kebutuhan untuk guru. Untuk mengetahui kenyataan di lapangan terkait proses pembelajaran yang selama ini dilaksanakan, peneliti melakukan observasi di tiga sekolah yang dipilih secara acak untuk menggali potensi dan masalah yang mungkin muncul dalam proses pembelajaran. Yakni SMA Negeri 8 Samarinda, SMA Negeri 11 Samarinda dan SMA Negeri 13 Samarinda. Lokasi tiga sekolah tersebut tersebar di Kota Samarinda. Masing-masing sekolah memiliki karakteristik yang berbeda sesuai dengan lingkungan dan kondisi sekolah tersebut sehingga pada tahap ujicoba dalam penelitian dan pengembangan nantinya akan mudah dalam menentukan sekolah yang dijadikan tempat ujicoba maupun tempat penerapan media yang dikembangkan. Sampel penelitian atau responden dari ketiga sekolah adalah kepala sekolah atau waka kurikulum untuk memberikan informasi mengenai kondisi sekolah, seluruh guru biologi kelas XII SMA dan juga siswa yang dipilih secara acak untuk memberikan informasi mengenai proses pembelajaran di sekolah. Instrumen penelitian berupa kuesioner sehingga data yang diperoleh adalah data kualitatif. Data dari kuesioner yang diisi oleh responden akan dianalisis secara deskriptif kualitatif.

\section{Hasil dan Pembahasan}

Berdasarkan hasil observasi yang dilakukan peneliti di tiga sekolah yakni SMA N 8 Samarinda, SMA N 11 Samarinda dan SMA N 13 Samarinda diperoleh bahwa proses pembelajaran di lapangan, belum dilaksanakan sebagaimana yang diharapkan. Yakni pendidik terutama guru biologi terkadang menjumpai kesulitan dalam proses penyampaian materi pembelajaran walaupun reaksi siswa sudah cukup antusias tetapi masih ada sebagian siswa yang pasif. Permasalahan yang dijumpai guru tersebut disebabkan karena tidak adanya media atau alat untuk beberapa materi biologi yang membutuhkan visualisasi objek yang mampu menerangkan rangkaian proses biologi yang tidak mampu diamati secara langsung atau bersifat abstrak. Akibatnya siswa dirasa tidak menguasai konsep materi dengan baik dikarenakan pemahaman siswa terhadap materi yang bersifat abstrak tersebut.

Materi-materi yang bersifat abstrak menurut guru-guru yang diobservasi adalah sintesis protein, pewarisan gen, fotosintesis, pembelahan sel dan metabolisme. Salah satu materi yang bersifat abstrak tersebut adalah pokok bahasan sintesis protein. $100 \%$ guru menyatakan bahwa pokok bahasan tersebut termasuk materi yang sulit. Dalam penyampaiannya pun terdapat kendala, yaitu sulitnya memahamkan siswa tiap tahapannya karena proses tersebut terjadi di dalam sel. Sehingga siswa sukar memahami dan dapat membayangkan proses tersebut dengan abstrak dan imajinatif. Akibatnya, dapat terjadi miskonsepsi siswa terhadap pokok bahasan protein tersebut. Hal ini sejalan dengan hasil penelitian oleh Murni (2013) yang mendapatkan hasil bahwa persentase miskonsepsi tertinggi ditemukan pada subkonsep "mekanisme sintesis protein" yaitu sebesar 25\% dibandingkan dengan materi yang lainnya. 


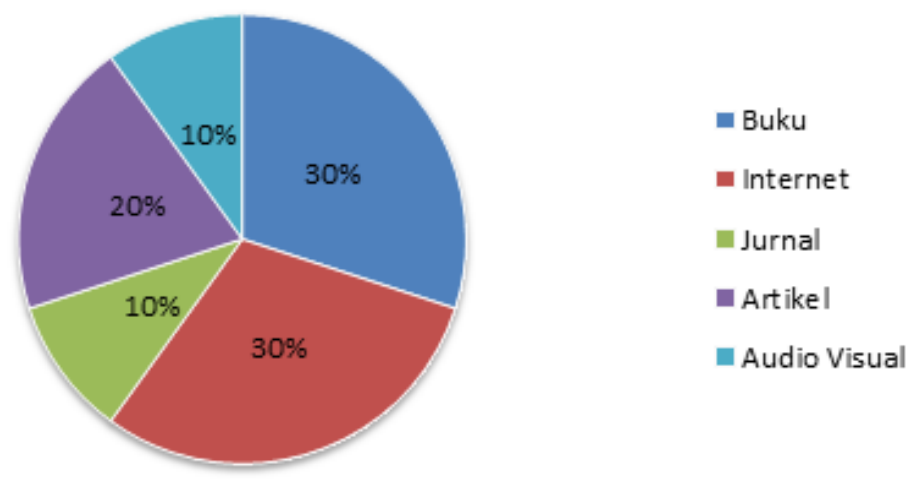

Gambar 1. Persentase Sumber Ajar Oleh Guru

Dari hasil observasi yang disajikan pada gambar 1, dapat disimpulkan bahwa penggunaan sumber ajar berupa media audio visual masih kurang optimal pemanfaatannya, yakni sangat rendah yaitu $10 \%$. padahal materi biologi lebih membutuhkan visualisasi objek dan penjelasan mendetail dan lebih real. 100\% guru menyatakan pula bahwa materi yang bersifat abstrak perlu disampaikan dengan menyajikan visualisasi objek dan juga menunjukkan dan menjelaskan proses biologi secara rinci. Oleh karena itu, penggunaan sumber ajar atau media yang tepat perlu mendapat perhatian lebih.

Hal tersebut di atas sejalan dengan pendapat Sudjana (2010) pengajaran akan lebih efektif apabila objek dan kejadian yang menjadi bahan pengajaran dapat divisualisasikan secara realistik menyerupai keadaan yang sebenarnya. Sedangkan Sungkono (2011) menyatakan bahwa pesan audio dalam pembelajaran dibutuhkan untuk memusatkan perhatian siswa. Sehingga pengajaran yang memililiki dimensi audio dan visual akan memberikan pesan yang diberikan akan lebih kuat berkat kedua sistem penyampaian tersebut.

Namun dalam kenyataannya, dalam persiapan pembelajaran sebanyak 66,7 \% guru tidak membuat sumber ajar sendiri tetapi memperoleh dari internet atau hanya menggunakan buku dari penerbit saja. Dari hasil observasi juga ditemukan bahwa 100\% siswa lebih tertarik jika belajar dengan menggunakan media yang bervariasi. Siswa lebih senang belajar dengan media yang menunjukkan cara kerja, gambargambar atau materi secara lebih mendetail (real) dibandingkan belajar dengan hanya menggunakan buku teks, modul atau buku ajar. Sumber ajar yang diperoleh dari internet jika tidak dipilah dengan benar dapat menimbulkan miskonsepsi siswa terhadap materi yang diajarkan. Sumber ajar dari penerbit juga dirasa kurang variatif dan tidak dapat dijadikan sebagai sumber acuan seutuhnya dalam penyampaian materi. Guru pernah mencoba membuat sendiri media atau sumber ajar, tetapi dalam pembuatannya menghadapi kendala seperti dalam pembuatannya sulit mengembangkan lebih rinci,sarana yang tidak memadai dan memerlukan ketelitian dan kesabaran yang lebih. Akibatnya media atau sumber ajar yang digunakan guru fungsinya tidak dapat dirasakan secara maksimal oleh siswa dan masih kurang paham terhadap materi yang diajarkan. Sehingga jika dilakukan penelitian dan pengembangan terkait media ajar berbasis audio visual akan sangat berguna dan membantu guru dalam menyampaikan materi dan untuk ke depannya guru dapat mengembangkan media audio visual secara mandiri.

Guru juga menyatakan bahwa sumber belajaryang dibutuhkan untuk dikembangkan dan dapat dijadikan sumber belajar mandiri 
untuk siswa adalah media belajar audio visual. Namun di sekolah-sekolah yang diobservasi baik guru maupun pihak pengembang lain belum pernah melakukan pengembangan media berbasis audio visual sebelumnya. Oleh karena itu perlu dikembangkan suatu media yang dapat mendemonstrasikan materi pembelajaran khususnya biologi yang bertujuan untuk mempermudah siswa dalam memahami konsep dari materi pembelajaran yang bersifat abstrak atau tidak diamati secara langsung. Dalam penelitian dan pengembangan yang akan dilakukan peneliti pada tahap selanjutnya terbatas hanya pada pokok bahasan sintesis protein. Mengingat miskonsepsi terhadap pokok bahasan tersebut sering terjadi dibanding materi lainnya dan pembatasan tersebut juga didasarkan oleh karena banyak pertimbangan seperti keterbatasan tenaga, waktu dan biaya.

\section{Simpulan dan Saran}

Kesimpulan yang dapat ditarik dari pembahasan yang telah dipaparkan adalah: 1) Penggunaan media pembelajaran sebagai sumber ajar pada proses pembelajaran biologi yang selama ini terjadi di lapangan belum dilakukan secara maksimal. Terdapat kendala penyampaian materi terutama materi yang sifatnya tidak dapat diamati secara langsung atau bersifat abstrak. 2) Pokok bahasan sintesis protein merupakan materi yang sulit, dalam penyampaiannya, guru membutuhkan media yang dapat memvisualisasikan proses sintesis protein untuk Kelas XII SMA dan menjelaskannya secara detail dan benar sehingga tidak terjadi miskonsepsi siswa terhadap pokok bahasan sintesis protein. 3) Media pembelajaran yang perlu dikembangkan dalam pembelajaran biologi pokok bahasan sintesis protein adalah berupa media audio visual.

Berdasarkan simpulan di atas, maka dapat disarankan sebagai berikut: 1) Mengingat pentingnya media yang dapat memvisualisasikan proses sintesis protein dan menjelaskannya secara detail dan benar maka perlu diadakan penelitian lanjutan yaitu pengembangan media audio visual pokok bahasan sintesis protein untuk kelas XII SMA. 2) Bagi setiap guru di SMA khususnya Kelas XII, diharapkan nantinya dapat menggunaka media berbasis audio visual pokok bahasan sintesis protein dan diharapkan juga dapat mengembangkan sendiri untuk beberapa materi lainnya yang bersifat abstrak. 3) Bagi pemerintah daerah maupun pimpinan sekolah dapat memeberikan dukungan baik moril maupun materiil terkait penggunaan media berbasis audio visual melalui pengadaan sarana dan prasarana di sekolah, peningkatan dan pemahaman pentingnya penggunaan media terhadap guru dan menciptakan rasa aman dan membangun motivasi dalam belajar untuk siswa.

\section{Daftar Pustaka}

BNSP. (2006). Panduan Penyusunan Kurikulum Tingkat Satuan Pendidikan Jenjang Pendidikan Dasar dan Menengah. Jakarta: BNSP.

Murni. (2013). Identifikasi Miskonsepsi Mahasiswa pada Konsep Subtansi Genetika Menggunakan Certainty of Response Index (CRI). Dipetik Maret 12, 2016, dari JURNAL FMIPA UNILA: http://jurnal.fmipa.unila.ac.id

Sudjana, N. (2010). Penilaian Hasil Proses Belajar Mengajar. Bandung: Rosdakarya.

Sugiyono. (2010). Metode Penelitian Kuantitatif, Kualitatif dan R\&D. Bandung: Alphabeta.

Sukiman. (2012). Pengembangan Media Pembelajaran. Yogyakarta: Pustaka Insan.

Sungkono. (2011). Penerapan Prinsip-prinsip Desain Pesan Dalam Program Kaset Audio. 
Yogyakarta: FIP UNY.

Susantini, E., Nuur, P., \& Thamrin, M.(2013). Kelayakan Teoritis Lembar Penilaian Pemahaman Diri Berbasis Metakognitif Pada Materi Genetika. Berkala Ilmiah Pendidikan Biologi Volume 2 Edisi 3, 286-289.

Suhermiati, I., Indana, S., \& Rahayu Y. S. (2015).

Analysis Of Student Misconception In Protein Synthesis Subject Material

Based On Biology Student Learning Result. Berkala Ilmiah Pendidikan Biologi Volume 4 Edisi 3, 985-990. 